\title{
A Comparison of the Efficacy of Dry Needling, Lidocaine Injection, and Oral Flurbiprofen Treatments in Patients with Myofascial Pain Syndrome: A Double-Blind (For Injection, Groups Only), Randomized Clinical Trial
}

\author{
Miyofasiyal Ağrı Sendromlu Hastalarda Kuru İğneleme, Lidokain Enjeksiyonu ve \\ Oral Flurbiprofen Tedavilerinin Etkinliklerinin Karşılaştırılması: \\ Çift Kör (Yalnızca İğneleme Grupları için), Randomize Bir Klinik Çalışma \\ Pınar Küçük EROĞLU, Özlem YILMAZ, ${ }^{1}$ Hatice BODUR, ${ }^{1}$ Can ATEŞ${ }^{2}$ \\ ${ }^{1}$ Department of Physical Medicine and Rehabilitation, Ankara Numune Training and Research Hospital, Ankara, Turkey \\ ${ }^{2}$ Department of Biostatistics, Medical Faculty of Ankara University, Ankara, Turkey
}

Objectives: The aim of this study was to assess and compare the efficiency of dry needling, lidocaine injection and oral flurbiprofen treatments in patients with myofascial pain syndrome (MPS) involving the neck and back region.

Patients and methods: A total of 60 patients ( 7 males, 53 females; mean age 33.7 years; range 18 to 50 years) were included in this prospective study. The patients were divided into three groups by block randomization. Each group was assigned to dry needling for trigger points, lidocaine injection (double blind) or oral flurbiprofen $200 \mathrm{mg} /$ day over seven days. All patients were also prescribed a standardized home exercise program based on stretching of the affected muscles. Before treatment and on the third and 14 days after treatment, pain severity was assessed by visual analog scale (VAS), degree of tenderness at the trigger points by algometry, active joint range of motion of the neck and shoulders by goniometry, and the quality of life by Nottingham Health Profile.

Results: There was a significant improvement in pain severity, trigger point tenderness, joint range of motion, and quality of life in all three groups on the third and $14^{\text {th }}$ days of treatment. No significant difference was found in treatment efficiency among the groups.

Conclusion: Treatments with dry needling, lidocain injection and oral flurbiprofen along with home exercises are all effective in the management of MPS.

Key words: Dry needling; flurbiprofen; lidocaine; myofascial pain syndrome.
Amaç: Bu çalışmada boyun ve sırt bölgesinde miyofasiyal ağrı sendromu (MAS) bulunan hastalarda kuru iğneleme, lidokain enjeksiyonu ve oral flurbiprofen tedavilerinin etkinliği karşılaştırıldı.

Hastalar ve yöntemler: Bu prospektif çalışmaya toplam 60 hasta ( 7 erkek, 53 kadın; ort yaş 33.7 yıl; dağılım 18-50 yıl) dahil edildi. Hastalar blok randomizasyon ile üç gruba ayrıldı. Bir gruba tetik noktalara kuru iğneleme, bir gruba lidokain enjeksiyonu (çift kör) ve diğer gruba yedi gün süresince $200 \mathrm{mg} / \mathrm{gün}$ oral flurbiprofen tedavisi verildi. Ayrıca hastaların tümüne tutulan kasın gerilmesini temel alan standart bir ev egzersiz programı da verildi. Tedavi öncesi ve tedaviden sonraki üçüncü ve 14. günlerde ağrı şiddeti, görsel analog ölçeği (GAÖ) ile tetik noktaların duyarlılık derecesi algometre ile boyun ve omuz aktif eklem hareket açıklıkları gonyometre ile ve yaşam kalitesi Nottingham Sağlık Profili ile değerlendirildi.

Bulgular: Üç grupta da tedaviden sonraki üçüncü ve 14. günlerde tedavi öncesine göre ağrı şiddeti, tetik nokta hassasiyeti, eklem hareket açıklıkları ve yaşam kalitesi açısından iyileşme saptandı. Tedavilerin etkinlikleri açısından gruplar arasında anlamlı fark bulunmadı.

Sonuç: Miyofasiyal ağrı sendromunun tedavisinde, ev egzersizleri ile birlikte kuru iğneleme, lidokain enjeksiyonu ve oral flurbiprofen tedavilerinin tümü etkindir.

Anahtar sözcükler: Kuru iğneleme; flurbiprofen; lidokain; miyofasiyal ağrı sendromu.

Received: July 11, 2012 Accepted: September 26, 2012

Correspondence: Özlem Yılmaz, M.D. Ankara Numune Eğitim ve Araştırma Hastanesi, Fiziksel Tıp ve Rehabilitasyon Kliniği, 06100 Altındağ, Ankara, Turkey. Tel: +90 312 - 3972308 e-mail: dr.ozlemyilmaz@gmail.com 
Myofascial pain syndrome (MPS) is a regional condition characterized by trigger points, which are hyperirritable foci located at the tense bands of skeletal muscle. ${ }^{[1,2]}$ It is also one of the major causes of musculoskeletal pain. ${ }^{[3]}$ The precise etiology and pathogenesis of MPS is unknown. In this syndrome, the essential goal of therapy is to deactivate the trigger point and abolish the vicious cycle of spasm-ischemia. A trigger point injection is a mode of treatment that has been mostly supported by scientific research and evidence ${ }^{[4-9]}$ and its use is generally supported when non-invasive treatments, such as educating the patients regarding the right posture to be used during daily living activities, exercising, overcoming mental stress, and avoiding the cold as much as possible, fail. ${ }^{[4]}$ However the results of the studies about the superiority of dry needling (DN) versus therapy via an injection of solution (e.g. local anesthetic, botulinum toxin, and saline) are controversial.

In daily practice, MPS can frequently be evaluated as myalgia, and only analgesics or non-steroidal antiinflammatory drugs (NSAIDs) are prescribed. There is a limited amount of literature that has investigated the use of NSAIDs in the treatment of MPS. ${ }^{[10,11]}$ However, it is interesting that the popularity of NSAIDs among patients is continuing. ${ }^{[4]}$ The aim of this study was to compare the efficiency of $\mathrm{DN}$ of the trigger points, LI to the trigger points, and oral flurbiprofen in the treatment of MPS.

\section{PATIENTS AND METHODS}

The present study included a total of 60 patients (7 males, 53 females; mean age 33.7 years; range 18 to 50 years) who applied to the physical medicine and rehabilitation outpatient clinic of Ankara Numune Training and Research Hospital, a tertiary hospital, between April 2009 and July 2009 with complaints of neck and back pain and were then diagnosed with MPS originating from the neck and back muscles. Diagnosis of MPS was made in accordance with the clinical findings as defined by Travell and Simons. ${ }^{[12]}$ Patients with diseases that could lead to neuropathy, such as diabetes mellitus (DM) and thyroid gland disorders or patients using medications that could lead to neuropathy were excluded from the study. In addition, patients with inflammatory rheumatic diseases, cardiovascular or pulmonary diseases, fibromyalgia syndrome, cervical radiculopathy or myelopathy were not included along with patients who were allergic to local anesthetics (for the injection groups), those who had undergone trigger point injection within the preceding two months because of MPS, those whose personalities were thought to be unsuitable for complying with the protocol requirements, those with bleeding disorders or those using medications that could promote bleeding, those who had previously undergone neck or shoulder surgery, and those who were pregnant.

All patients were informed about the study before it began, and their written consent was obtained. The study was approved by the ethics committee of the General Directorate for pharmaceuticals and pharmacy. The 60 subjects were assigned to either the DN, LI, or oral flurbiprofen groups using block randomization to ensure an equal number of patients in each group. Random allocation software (RAS) was used to determine which patients would be in each group. ${ }^{[13]}$ Since gender was not a factor which could affect the response of the patients to the treatment, it was not taken into consideration in the course of randomization. The first investigator considered whether the patient was eligible for the study and sent those who were qualified to the second investigator after a detailed physical examination and gathering of measurements. Localizations of active trigger points were determined and marked in all patients by the first investigator. As the post-treatment algometric evaluations were to be performed at these same localizations, paint that could only be removed after a short period of time was used to mark them.

Pain severity was examined by the visual analog scale (VAS) ${ }^{[14]}$ while quality of life was evaluated by the Nottingham Health Profile (NHP). A validation study of the Turkish version of this test was performed by Küçükdeveci et al., ${ }^{[15]}$ and this version was used in the present study. In all patients, active range of motion of the neck (neck flexion, extension, right and left lateral flexion, and right and left rotation) and shoulder joint (abduction, adduction, flexion, extension, internal rotation, and external rotation of both shoulders) were measured with the goniometer and recorded. For the marked trigger points, degree of sensitivity was measured by an algometer (Baseline, Italy) and calculated as $\mathrm{kg} / \mathrm{cm}^{2}$. Three measurements were performed for every trigger, and their average was noted and recorded. Studies performed to date have shown that in MPS, the use of an algometer is safe in terms of determining the tenderness of the trigger points. ${ }^{[16-19]}$ The second investigator identified the patient groups using the RAS system. If the patient was in the oral flurbiprofen group, the tablets were given to the patients along with an explanation of how 
and when to take them, and if the patient was in one of the needling groups, the procedures were performed by the second investigator. The patients were made not aware of whether they were injected with a solution or whether DN was performed. A standardized home exercise program was given to each patient and a demonstration of these exercises was provided by the second investigator to all participants. The first investigator reevaluated the patients on the third and $14^{\text {th }}$ day of treatment and recorded the outcomes. Since the first investigator would understand that the patients without needle marks were in the oral flurbiprofen group when measurements for tenderness via algometry in the control visits were taken, double blindedness was provided for the needling groups only.

Needling was performed on all active trigger points in the DN and LI groups in accordance with the technique described by Travell and Simons. ${ }^{[12]}$ Injections were done with the patients lying on prone position. Once a trigger point was located and the overlying skin had been cleansed with alcohol, the taut band was pinched between the thumb and index finger, and the needle was inserted $1-2 \mathrm{~cm}$ away from the targeted trigger point to be able reach it at an angle of 30 degrees to the skin. The plunger was withdrawn to ensure the needle was not in a blood vessel. An injection of $0.2 \mathrm{ml}$ of $2 \%$ lidocaine solution was also given. Following that, the needle was withdrawn to the subcutaneous tissue, and the trigger point and surrounding areas were injected and pricked repeatedly with rapid movements until the local twitch response was no longer elicited or resistant muscle tautness was no longer perceived. ${ }^{[20]}$ The injection site was then compressed for about two minutes to enable hemostasis. A 22-gauge, 1.5-inch or a 21-gauge, 2-inch needle was used depending on the depth of the trigger points from the surface. In the DN group, the same procedure was followed without the injection of any substance. Throughout the study, these patients were instructed to avoid analgesics, NSAIDs, myorelaxants, anxiolytics, and antidepressants. For patients in the oral flurbiprofen group, the tablets were given $2 \times 100 \mathrm{mg} /$ day for seven days, and throughout the study, these patients were also instructed to avoid the same medications.

All patients were provided with a home exercise program consisting of active and active-assistive range of motion exercises for the neck and stretching exercises for the neck and back muscles. The program consisted of three sessions, and each session repeated every motion 20 times.
All of the patients were reevaluated on the third and $14^{\text {th }}$ days after their treatments by the first investigator. Their pain severity, degree of tenderness at the trigger points, neck range of motion, and quality of life were reexamined and recorded by the first investigator. The patients were asked on the first visit whether they were doing the exercises properly at home, and this was verified at the follow-up visit.

No complications were observed due to the interventions, and all of the patients fully completed the study.

\section{Statistical analysis}

Data analyses were performed with SPSS (SPSS Inc., Chicago, Illinois, USA) for Windows version 11.5 and SAS $^{\circledR} 9.0$ (SAS Institute Inc., Cary, North Carolina, USA). The demographic characteristics of the patients in each group were compared by a chi-square test as well as Student's t-test or the Mann-Whitney U test, as appropriate, and mean \pm standard deviation (SD), median (minimum-maximum) for metric variables, and frequency (percent) for categorical variables were used as descriptive statistics.

The nonparametric approach to two-way factorial repeated measures design (treatment group and time as factors) was used to determine both betweengroup and within-group differences. ${ }^{[21]}$ In this study, the F1-LD-F1 design was used to test the average treatment group effect, time effect, and the effect of their interaction by an analysis of variance (ANOVA)type test statistic (Fn). In addition to the median (minimum-maximum), the relative treatment effect (RTE) was used as a descriptive statistic in this design. This shows the tendency for the participants in one group to have higher (or lower) scores compared with the scores of all participants in a study. The RTE can range between 0 and 1 . If the null hypothesis is true, all groups should have an RTE of 0.50.SAS macros for the F1-LD-F1 design that was used for analysis. A value of $\mathrm{p}<0.05$ was considered to be statistically significant.

\section{RESULTS}

Although there were no significant differences between the groups in terms of age and duration of symptoms, the gender distribution was different (Table 1), but since gender is not a factor that affects the response to the treatments in MPS, the authors ignored this difference. The descriptive statistics of the groups are presented in Tables 2 and 3. The groups were similar in terms of pre-treatment algometric sensitivity, VAS-pain scores, 


\begin{tabular}{|c|c|c|c|c|c|c|c|c|c|c|c|c|c|}
\hline & \multicolumn{4}{|c|}{ DN group $(n=20)$} & \multicolumn{4}{|c|}{ LI group $(n=20)$} & \multicolumn{4}{|c|}{ OF group $(n=20)$} & \multirow[b]{2}{*}{$p$} \\
\hline & $\mathrm{n}$ & Median & Min.-max. & Mean \pm SD & $\mathrm{n}$ & Median & Min.-max. & Mean \pm SD & $\mathrm{n}$ & Median & Min.-max. & Mean \pm SD & \\
\hline \multicolumn{14}{|l|}{ Gender } \\
\hline Female & 19 & & & & 14 & & & & 20 & & & & \\
\hline Male & 1 & & & & 6 & & & & 0 & & & & $0.004^{\times}$ \\
\hline & & & & $33.75 \pm 8.10$ & & & & $32.85 \pm 9.06$ & & & & $34.55 \pm 8.30$ & 0.819 \\
\hline \multicolumn{14}{|l|}{ Symptom duration } \\
\hline (months) & 48 & $2-120$ & & & 36 & $3-120$ & & & 24 & $1-72$ & & & 0.237 \\
\hline
\end{tabular}

\begin{tabular}{|c|c|c|c|c|c|c|}
\hline & \multicolumn{3}{|c|}{ Treatment groups } & \multicolumn{3}{|c|}{ Time } \\
\hline & LI & $\mathrm{DN}$ & OF & Day 0 & Day 3 & Day 14 \\
\hline Algometric sensitivity & $0.52[4(3-13)]$ & $0.51[4(3-14)]$ & $0.45[4(3-7)]$ & $0.28[3(3-6)]$ & $0.60[4(3-14)]$ & $0.60[5(3-14)]$ \\
\hline VAS-pain scores & $0.46[3(0-10)]$ & $0.56[5(0-10)]$ & $0.46[3.5(0-10)]$ & $0.73[6.5(2-10)]$ & $0.40[3(0-10)]$ & $0.35[2.5(0-10)]$ \\
\hline Right-lateral flexion & $0.53[47.5(30-85)]$ & $0.51[50(20-70)]$ & $0.44[45(25-70)]$ & $0.35[45(20-70)]$ & $0.53[50(25-80)]$ & $0.60[55(35-80)]$ \\
\hline Left-lateral flexion & $0.56[50(25-80)]$ & $0.45[45(20-70)]$ & $0.47[45(20-70)]$ & $0.36[45(20-70)]$ & $0.55[50(25-80)]$ & $0.58[50(25-70)]$ \\
\hline Right rotation & $0.58[70(35-90)]$ & $0.45[65(40-90)]$ & $0.46[65(35-90)]$ & $0.35[60(35-70)]$ & $0.56[70(40-90)]$ & $0.57[70(40-90)]$ \\
\hline Left rotation & $0.56[70(30-85)]$ & $0.50[70(35-90)]$ & $0.42[65(35-85)]$ & $0.38[65(35-85)]$ & $0.56[70(45-90)]$ & $0.55[70(30-90)]$ \\
\hline
\end{tabular}

Table 3. Descriptive statistics for Nottingham Health Profile

\begin{tabular}{llcllll}
\hline & \multicolumn{3}{c}{ Treatment groups } & & \multicolumn{2}{c}{ Time } \\
\cline { 2 - 6 } & \multicolumn{1}{c}{ LI } & \multicolumn{1}{c}{ DN } & \multicolumn{1}{c}{ OF } & \multicolumn{1}{c}{ Day 0 } & \multicolumn{1}{c}{ Day 3 } \\
\hline NHP-Pain & $0.48[29(0-100)]$ & $0.53[43(0-100)]$ & $0.48[29(0-100)]$ & $0.72[71(14-100)]$ & $0.37[14(0-100)]$ & $0.39[14(0-100)]$ \\
NHP-Physical activity & $0.50[25(0-100)]$ & $0.49[13(0-100)]$ & $0.49[13(0-88)]$ & $0.65[38(0-100)]$ & $0.41[13(0-63)]$ & $0.42[13(0-88)]$ \\
NHP-Fatigue & $0.44[50(0-100)]$ & $0.53[50(0-100)]$ & $0.51[50(0-100)]$ & $0.66[100(0-100)]$ & $0.41[25(0-100)]$ & $0.62[50(0-100)]$ \\
NHP-Sleep & $0.45[0(0-100)]$ & $0.56[20(0-100)]$ & $0.48[0(0-80)]$ & $0.66[50(0-100)]$ & $0.40[0(0-80)]$ & $0.42[0(0-80)]$ \\
NHP-Social isolation & $0.50[0(0-100)]$ & $0.54[20(0-100)]$ & $0.44[0(0-100)]$ & $0.56[20(0-100)]$ & $0.47[0(0-100)]$ & $0.44[0(0-100)]$ \\
NHP-Emotional reactions & $0.47[38(0-100)]$ & $0.54[50(0-100)]$ & $0.48[38(0-100)]$ & $0.67[75(0-100)]$ & $0.39[25(0-88)]$ & $0.43[25(0-100)]$ \\
\hline \multicolumn{7}{l}{ Cells represent RTE [Median (minimum-maximum)]; NHP: Nottingham Health Profile; LI: Lidocaine injection; DN: Dry needling; OF: Oral flurbiprofen. }
\end{tabular}

restrictions regarding neck range of motion, and NHP. The $p$ values are provided in Tables 4 and 5 .

The number of active trigger points was between one and six in all the groups. In the LI group, the median number of active trigger points was three, whereas it was two in the DN and oral flurbiprofen groups. The groups were similar in terms of the number of active trigger points, $(p=0.67)$ and these were localized at the trapezius, supraspinatus, and rhomboideus muscles. There were not similarities in terms of the muscles involved. This difference was also ignored because the muscle that is involved is not a factor that influences treatment response. The distributions of the trigger points to the muscles are given in Table 6 .

There were no restrictions of movement that involved neck flexion and extensions or shoulder movements in all directions in any of the patients. In all groups, the pre-treatment algometric sensitivity and VAS-pain scores decreased and the degree of neck lateral flexion and rotation significantly increased on the third and 14th days of follow-up. The quality of life was also significantly improved at the first and second controls. (Figure 1 and 2; Tables 4 and 5) These results showed that the DN, LI, and oral flurbiprofen were efficient in the treatment of MPS.

When inter-group comparisons were performed in terms of improvements shown via algometric sensitivity, VAS-pain scores, cervical range of rotation, and lateral flexion along with all of the NHP subdivisions, except for fatigue on the third and $14^{\text {th }}$ days, revealed no significant differences (Tables 4 and 5). The NHP fatigue scores improved in all three groups on the third and $14^{\text {th }}$ days when compared with the pre-treatment values. However, in 
Table 4. Inter-time and inter-group comparisons for tenderness of trigger points, visual analog scale-pain scores, and neck range of motion

\begin{tabular}{|c|c|c|c|c|c|c|}
\hline & \multicolumn{2}{|c|}{ Treatment } & \multicolumn{2}{|c|}{ Time } & \multicolumn{2}{|c|}{ Interaction } \\
\hline & $F_{n}$ & $p$ & $\mathrm{~F}_{\mathrm{n}}$ & $p$ & $F_{n}$ & $p$ \\
\hline Algometric sensitivity & 0.58 & 0.55 & 108.28 & $<0.001^{\star}$ & 1.22 & 0.29 \\
\hline VAS-pain scores & 2.073 & 0.13 & 73.97 & $<0.001^{\star}$ & 0.41 & 0.76 \\
\hline Right-lateral flexion & 0.854 & 0.42 & 38.74 & $<0.001^{*}$ & 0.685 & 0.56 \\
\hline Left-lateral flexion & 1.29 & 0.27 & 26.83 & $<0.001^{*}$ & 0.55 & 0.67 \\
\hline Right rotation & 2.174 & 0.11 & 23.76 & $<0.001^{\star}$ & 0.40 & 0.79 \\
\hline Left rotation & 1.92 & 0.14 & 17.30 & $<0.001^{\star}$ & 0.70 & 0.56 \\
\hline
\end{tabular}

Table 5. Inter-time and inter-group comparisons for the Nottingham Health Profile

\begin{tabular}{|c|c|c|c|c|c|c|}
\hline & \multicolumn{2}{|c|}{ Treatment } & \multicolumn{2}{|c|}{ Time } & \multicolumn{2}{|c|}{ Interaction } \\
\hline & $F_{n}$ & $p$ & $F_{n}$ & $p$ & $\mathrm{~F}_{\mathrm{n}}$ & $p$ \\
\hline NHP-Pain & 0.67 & 0.49 & 53.79 & $<0.001^{\star}$ & 0.17 & 0.93 \\
\hline NHP-Physical activity & 0.02 & 0.97 & 27.00 & $<0.001^{*}$ & 0.73 & 0.56 \\
\hline NHP-Fatigue & 1.13 & 0.32 & 34.10 & $<0.001^{*}$ & 3.06 & $0.02^{*}$ \\
\hline NHP-Sleep & 1.91 & 0.14 & 38.23 & $<0.001^{\star}$ & 1.78 & 0.13 \\
\hline NHP-Social isolation & 1.76 & 0.30 & 5.99 & $0.002^{*}$ & 1.33 & 0.25 \\
\hline NHP-Emotional reactions & 0.83 & 0.42 & 39.35 & $<0.001^{*}$ & 1.38 & 0.23 \\
\hline
\end{tabular}

the LI group, improvement to statistically significant values was not attained as of the third day follow-up visit (NHP scores: 0.68 on day zero and 0.41 on the third day; $p>0.05$ ), but this was not thought to be clinically important.

\section{DISCUSSION}

We found that LI, DN, and oral flurbiprofen were all effective in the treatment of patients with MPS, and no differences were found with regard to the efficiency of these treatments. We only found a difference between the groups related to improvements in the fatigue subcategory of the NHP. We also discovered that in the LI group, improvement as of the third day of follow-up did not reach statistically significant values, but this was not thought to be clinically important.
In daily practice, MPS is frequently diagnosed as myalgia, and only simple analgesics or NSAIDs may be prescribed. One of the reasons we chose the NSAID group as one of the treatment options in our study was that we were curious about the results of patients who were prescribed NSAIDs without a specific diagnosis for their condition. In addition, in the literature, we could not find a study investigating the effect of oral NSAIDs used in the treatment of MPS. Our study results showed that using NSAIDs in combination with stretching exercises of the involved muscles was effective in the treatment of MPS, but since there was no group using NSAIDs who did not exercise in this study, our results do not actually represent the outcome of patients that were prescribed NSAIDs without a specific diagnosis for their condition.

Table 6. Muscular trigger point localizations by groups

\begin{tabular}{|c|c|c|c|c|c|c|}
\hline & \multicolumn{2}{|c|}{ LI group } & \multicolumn{2}{|c|}{ DN group } & \multicolumn{2}{|c|}{ OF group } \\
\hline & $\mathrm{n}$ & $\%$ & $\mathrm{n}$ & $\%$ & $\mathrm{n}$ & $\%$ \\
\hline \multicolumn{7}{|c|}{ Muscular trigger point localization } \\
\hline Trapezius & 44 & 73.3 & 41 & 78.8 & 52 & 94.5 \\
\hline Rhomboideus & 14 & 23.3 & 6 & 11.5 & 3 & 5.5 \\
\hline Supraspinatus & 2 & 3.3 & 5 & 9.6 & - & \\
\hline Total & 60 & & 52 & & 55 & \\
\hline
\end{tabular}


Treatment efficiency was evaluated by changes in the VAS-pain scores, tenderness at the trigger points, the NHP, and increases in neck range of motion. The fact that there were no significant differences between the needling and NSAID groups was not surprising because no inflammation exists that we know of at the active trigger points. When the physiopathology of MPS is analyzed, there is local ischemia at the trigger points as a result of elongated contraction which causes the release of local paincausing substances. These substances (histamine, kinins, potassium, and prostaglandins) stimulate the nociceptors at the related area and lead to local sensitivity. These stimulations are then thought to cause reflecting pain by a reflex mechanism via the spinal cord. ${ }^{[22]}$ It is well known that NSAIDs inhibit cyclooxygenase, thus suppressing the prostaglandin synthesized from arachidonic acid. ${ }^{[23]}$ The efficiency of NSAIDs in our study can be explained by their ability to decrease local prostaglandin synthesis. It is possible that as pain decreases with NSAIDs, patients start using their muscles more actively. When this occurs, the involved muscles reach their optimum length, and with reflex relaxation, the stretched bands dissolve, thus breaking the vicious cycle of contraction-ischemia-contraction. This mechanism

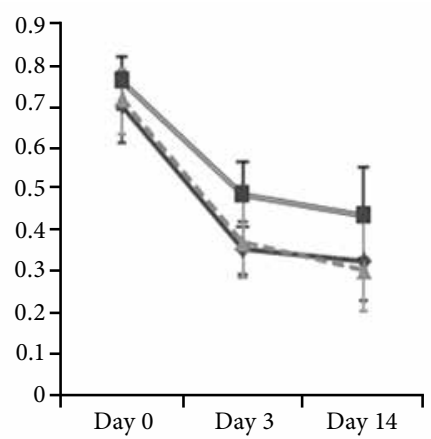

(a)

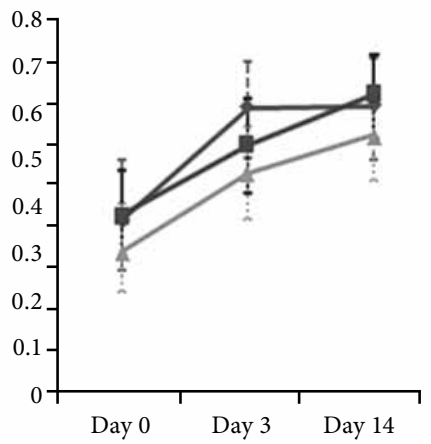

(c)

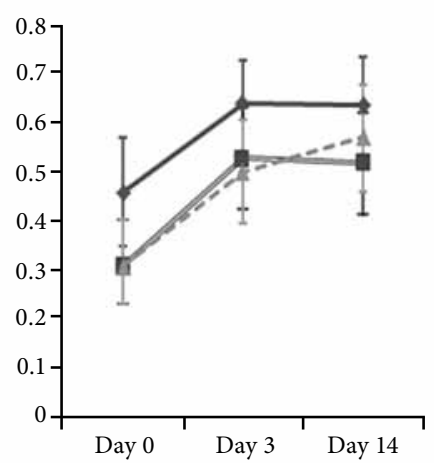

(e)
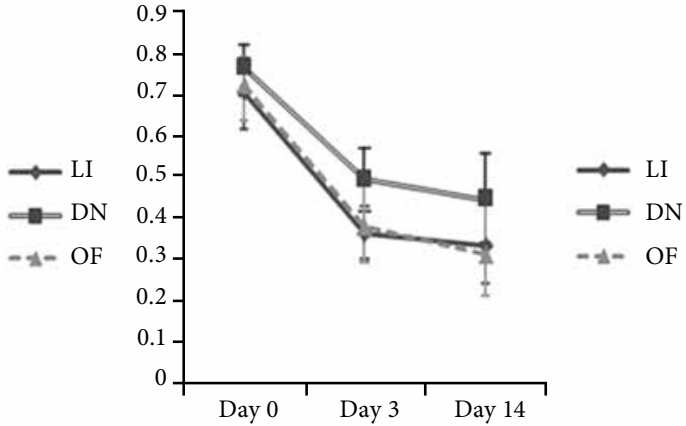

(b)
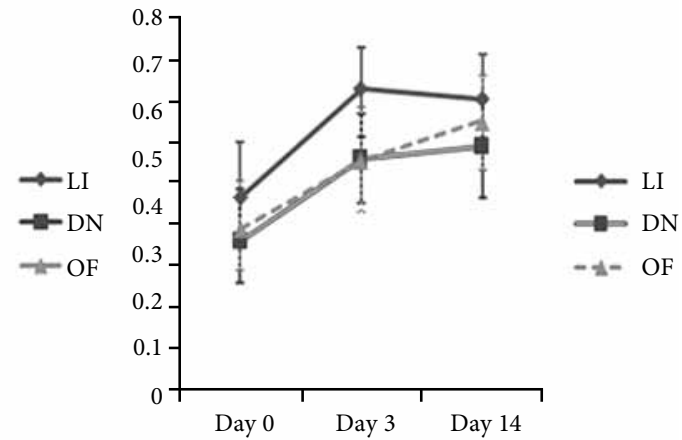

(d)
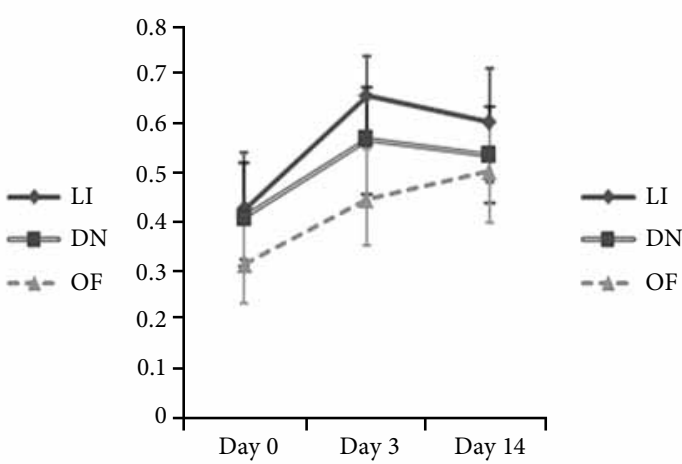

(f)

Figure 1. Changes in (a) algometric tenderness at the trigger points, (b) visual analog scale-pain scores, (c) cervical lateral flexion to the right, (d) cervical lateral flexion to the left, (e) cervical rotation to the right, (f) cervical rotation to the left over time. LI: Lidocaine injection; DN: Dry needling; OF: Oral flurbiprofen. 
could explain why the NSAID treatment was as efficient as the needling treatments in this study. Patients were given a home exercise program for their involved muscles. Regular exercise can deactivate trigger points or prevent the formation of new trigger points. We believe that the continued improvement at the $14^{\text {th }}$ day control could have been the result of the patients maintaining this exercise routine.

Although DN is a cheaper treatment than NSAIDs. it is a painful process that requires extra time on the part of physicians outside of their outpatient clinic examination hours. In addition, there is also a minimal risk of infection and pneumothorax with this

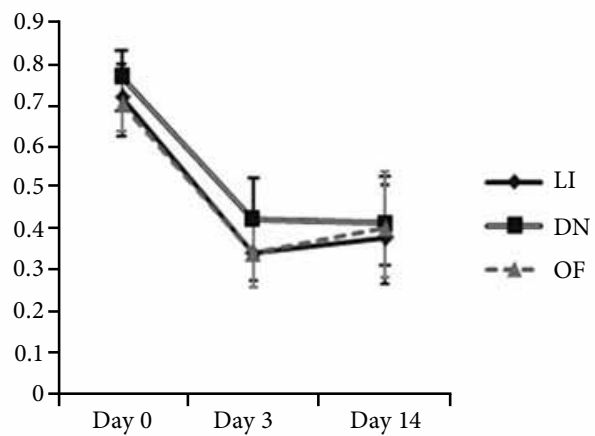

(a)

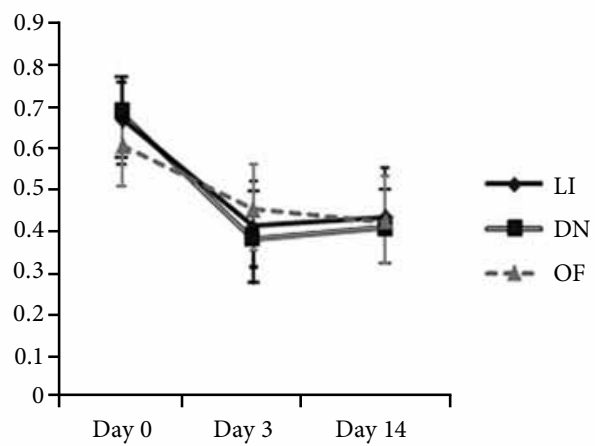

(c)

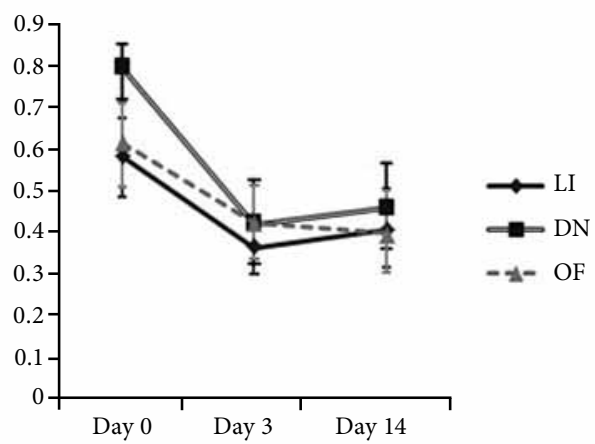

(e) procedure. ${ }^{[24]}$ Lidocaine injection is more expensive than $\mathrm{DN}$, and it carries a risk of anaphylaxis along with skeletal muscle toxicity, a rare adverse effect associated with local anesthetics. Furthermore, intramuscular injection of these agents can lead to reversible myonecrosis. The extent of muscle damage is dose-dependent and worsens with serial or continuous applications. ${ }^{[25]}$ Moreover, whether DN or injection of a substance is performed to relieve the pain, patients run the risk of dependency when needling is used as the primary treatment. ${ }^{[4]}$ Therefore, NSAIDs can be the first line of therapy in patients who have not used these agents before and/or for those who are at low

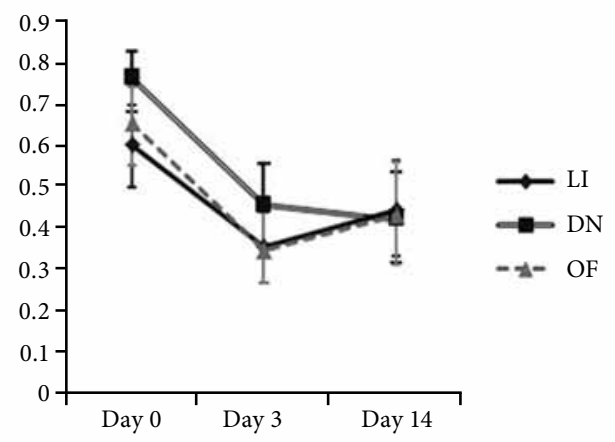

(b)

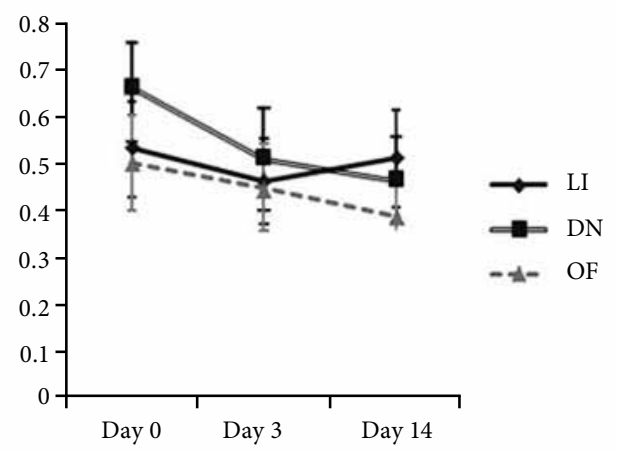

(d)

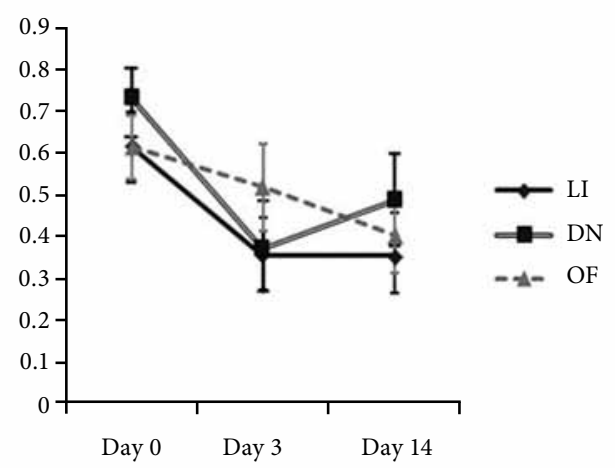

(f)

Figure 2. Changes of the Nottingham Health Profile subdivisions over time with regard to (a) pain, (b) emotional reactions, (c) physical activity, (d) social isolation, (e) sleep, and (f) fatigue. LI: Lidocaine injection; DN: Dry needling; OF: Oral flurbiprofen. 
risk in terms of adverse effects (young patients and those who do not have hypertension, DM, or liver, kidney, or gastrointestinal system diseases). However, it is also recommended that a home exercise program be used concomitantly with posture education and modification of daily living activities.

Several substances (local anesthetics, botulinum toxin, saline solution, corticosteroids) have been used in injection treatments, and their effectiveness has been investigated. ${ }^{[6-8,26-28]}$ Apart from Hong et al., ${ }^{[6]}$ who reported on the effect of needling treatments rather than injected substances, the other studies have suggested that local anesthetics are more efficient than DN. For instance, in the study by Affaitati et al., ${ }^{[29]}$ the efficiency of bupivacaine injections, lidocaine patches, and placebo patches were compared in 60 patients with MPS, and the patients' pain during rest and activities along with any changes in pain during daily living activities and work as well as any changes in pain in accordance with mood were questioned. Treatments with lidocaine patches and bupivacaine injections were revealed to be significantly beneficial when compared with a placebo. The fact that both of these groups benefited from these treatments supports the idea that the treatment efficiency of bupivacaine injections depends on the substance injected rather than the mechanical effect of needling. In our study, both $\mathrm{DN}$ and LI treatments were efficient, and there were no significant differences regarding their effectiveness. Thus, the present study supports the previous studies that have suggested that the mechanical effect of needling is beneficial as a form of treatment.

Dry needling does not lead to hypoesthesia in patients. However, local anesthetics spread to the surrounding environment during infiltration and block the pain sensation at that region. Hence, if the needle does not reach the trigger point or does not eliminate it, then the patient will not be able to feel this. In DN, if the patient feels no relief after the procedure, a trigger point (or points) can be established with a new palpation, allowing for a new opportunity to try the procedure. Another advantage of DN over LI is that there is no need to fear an anaphylactic reaction if the patient feels unwell after needling, as is often the case following any injection or needle puncture. ${ }^{[5]}$ However, a physician must be aware of the hypotensive symptoms that are frequently associated with vagal stimulation. ${ }^{[2]}$

In our study, the VAS-pain scores, NHP, and algometric sensitivity improved in all three groups, and no differences were discovered between the groups in terms of these improvements. Hong ${ }^{[6]}$ compared the efficiency of DN and LI in a study consisting of 58 patients with MPS in the upper trapezius muscle. Subjective pain severity was evaluated by VAS, the pain threshold by algometry, and neck range of motion by goniometry in the Hong study. The VAS, algometric sensitivity, and range of motion improved in both injection groups, and the differences between the groups were not significant immediately after treatment. This was similar to our results; however, unlike our study, the pain intensity was lower in the LI group after two weeks.

Stretching exercises form the basis of exercise treatment for MPS. The aim is to correct muscle shortening and stiffness, the primary reasons for the patients pain. The most effective type of exercise is slow, supported stretching that includes range of motion. In the controlled study by Hanten et al., ${ }^{[30]}$ the patients had MPS that involved the neck and back muscles. One group was given stretching exercises as a home program for five days while the other group was prescribed self-massage with massage appliances and active range of motion exercises. The stretching exercise group showed significant improvement in their pain analog scores and pain pressure threshold. In our study, all groups were taught stretching exercises for their back and neck muscles and were prescribed a home exercise program. The patients in all three groups benefited from this treatment, and their improvement continued at the $14^{\text {th }}$ day follow-up, which we believe was a direct result of their exercise routine.

The main limitation of this study was that we did not have a group whose only treatment option was exercise. It is possible that stretching exercises alone could deactivate the trigger points, so if there had been a group treated only with a home exercise program, we could have observed its benefits more realistically.

In addition, since no long-term results after the $14^{\text {th }}$ day were compared in this study, we could make no conclusions regarding the long-term efficiency of these treatments.

In conclusions, oral flurbiprofen, $\mathrm{DN}$, and $\mathrm{LI}$ together with stretching exercises were found to be effective in treating MPS, and no differences were detected regarding their efficiency. We beleive that NSAIDs can be used as a first line of therapy in patients that have not used them before and in patients who are at low risk in terms of adverse effects. However, needling treatments are also another option for the first line of therapy. The choice should be left to the physician. Additionally, a home exercise program 
should be included in conjunction with all other treatment options.

\section{Declaration of conflicting interests}

The authors declared no conflicts of interest with respect to the authorship and/or publication of this article.

\section{Funding}

The authors received no financial support for the research and/or authorship of this article.

\section{REFERENCES}

1. Skootsky SA, Jaeger B, Oye RK. Prevalence of myofascial pain in general internal medicine practice. West J Med 1989;151:157-60.

2. Alvarez DJ, Rockwell PG. Trigger points: diagnosis and management. Am Fam Physician 2002;65:653-60.

3. Yap EC. Myofascial pain--an overview. Ann Acad Med Singapore 2007;36:43-8.

4. Borg-Stein J, Simons DG. Focused review: myofascial pain. Arch Phys Med Rehabil 2002;83:S40-7, S48-9.

5. Lewit K. The needle effect in the relief of myofascial pain. Pain 1979;6:83-90.

6. Hong CZ. Lidocaine injection versus dry needling to myofascial trigger point. The importance of the local twitch response. Am J Phys Med Rehabil 1994;73:256-63.

7. Venâncio Rde A, Alencar FG, Zamperini C. Different substances and dry-needling injections in patients with myofascial pain and headaches. Cranio 2008;26:96-103.

8. Graboski CL, Gray DS, Burnham RS. Botulinum toxin A versus bupivacaine trigger point injections for the treatment of myofascial pain syndrome: a randomised double blind crossover study. Pain 2005;118:170-5.

9. Cummings TM, White AR. Needling therapies in the management of myofascial trigger point pain: a systematic review. Arch Phys Med Rehabil 2001;82:986-92.

10. Hsieh LF, Hong CZ, Chern SH, Chen CC. Efficacy and side effects of diclofenac patch in treatment of patients with myofascial pain syndrome of the upper trapezius. J Pain Symptom Manage 2010;39:116-25. doi: 10.1016/j. jpainsymman.2009.05.016.

11. Frost A. Diclofenac versus lidocaine as injection therapy in myofascial pain. Scand J Rheumatol 1986;15:153-6.

12. Tunks E, Crook J. Regional soft tissue pains: alias myofascial pain? Baillieres Best Pract Res Clin Rheumatol 1999;13:345-69.

13. Saghaei M. Random allocation software for parallel group randomized trials. BMC Med Res Methodol 2004;4:26.

14. Huskisson EC. Measurement of pain. Lancet 1974;2:1127-31.

15. Kücükdeveci AA, McKenna SP, Kutlay S, Gürsel Y, Whalley D, Arasil T. The development and psychometric assessment of the Turkish version of the Nottingham Health Profile. Int J Rehabil Res 2000;23:31-8.
16. Jaeger B, Reeves JL. Quantification of changes in myofascial trigger point sensitivity with the pressure algometer following passive stretch. Pain 1986;27:203-10.

17. Delaney GA, McKee AC. Inter- and intra-rater reliability of the pressure threshold meter in measurement of myofascial trigger point sensitivity. Am J Phys Med Rehabil 1993;72:136-9.

18. Sciotti VM, Mittak VL, DiMarco L, Ford LM, Plezbert J, Santipadri E, et al. Clinical precision of myofascial trigger point location in the trapezius muscle. Pain 2001;93:259-66.

19. Reeves JL, Jaeger B, Graff-Radford SB. Reliability of the pressure algometer as a measure of myofascial trigger point sensitivity. Pain 1986;24:313-21.

20. Simons DG, Travell JG, Simons LS. Myofascial pain and dysfunction: the trigger point manual. 2nd ed. Vol. 1. Baltimore: Williams \& Wilkins; 1999.

21. Brunner E, Domhof S, Langer F. Nonparametric analysis of longitudinal data in factorial experiments. New York: John Wiley \& Sons; 2002.

22. Celiker R. Myofascial pain syndrome: Diagnosis and treatment. J Rheum Med Rehab 1992;3:155-60.

23. Patrono C. Non-steroidal anti-inflammatory drugs. In: Hochberg MC, Silman AJ, Smolen JS, Weinblatt ME, Weisman $\mathrm{MH}$, editors. Rheumatology. Philadelphia: Mosby Elsevier; 2008. p. 403-11.

24. Lavelle ED, Lavelle W, Smith HS. Myofascial trigger points. Anesthesiol Clin 2007;25:841-51.

25. Cheng J, Abdi S. Complications of joint, tendon, and muscle injections. Tech Reg Anesth Pain Manag 2007;11:141-7.

26. Göbel H, Heinze A, Reichel G, Hefter H, Benecke R; Dysport myofascial pain study group. Efficacy and safety of a single botulinum type A toxin complex treatment (Dysport) for the relief of upper back myofascial pain syndrome: results from a randomized double-blind placebo-controlled multicentre study. Pain 2006;125:82-8.

27. Ga H, Koh HJ, Choi JH, Kim CH. Intramuscular and nerve root stimulation vs lidocaine injection to trigger points in myofascial pain syndrome. J Rehabil Med 2007;39:374-8.

28. Venancio Rde A, Alencar FG Jr, Zamperini C. Botulinum toxin, lidocaine, and dry-needling injections in patients with myofascial pain and headaches. Cranio 2009;27:46-53.

29. Affaitati G, Fabrizio A, Savini A, Lerza R, Tafuri E, Costantini R, et al. A randomized, controlled study comparing a lidocaine patch, a placebo patch, and anesthetic injection for treatment of trigger points in patients with myofascial pain syndrome: evaluation of pain and somatic pain thresholds. Clin Ther 2009;31:70520. doi: 10.1016/j.clinthera.2009.04.006.

30. Hanten WP, Olson SL, Butts NL, Nowicki AL. Effectiveness of a home program of ischemic pressure followed by sustained stretch for treatment of myofascial trigger points. Phys Ther 2000;80:997-1003. 